\title{
THE IMPORTANCE OF SOCIAL MEDIA IN FINANCIAL SERVICES' SELLING
}

\author{
KAZIMIERZ CYRAN, ${ }^{1}$ SŁAWOMIR DYBKA ${ }^{2}$ \\ University of Rzeszow, Faculty of Economics, Department of Marketing and Entrepreneurship, POLAND \\ ${ }^{1}$ e-mail: kcyran@ur.edu.pl \\ ${ }^{2}$ e-mail: slawomirdybka@gmail.com
}

\begin{abstract}
RECEIVED
ACCEPTED

7 August 2017

15 December 2017

JEL

CLASSIFICATION

G20, M30, M37

KEYWORDS

social media, financial services, customer

ABSTRACT

The growing popularity of social media engage business for using this channel of marketing communication. Financial institutions are trying to rebuild client trust so social media could be theoretically an important tool. But it turns out that it is not, at least not always. Therefore social media may be a complementary communication channel and cannot be ignored completely. Own research confirms that decisions about buying financial services are determined by other factors such as fees and commissions, range of services or number of ATMs.
\end{abstract}

\section{Introduction}

The highly competitive market players try to use efficient and effective tools to communicate with customers, trying to create stable relationships based on various factors. Growing popularity of the social media causes businesses and institutions to actively use them in marketing communications. Therefore, the article attempts to answer the research question: have the social media and the information published there a similar influence on 
purchasing decisions in financial services as in the other types of services? It seems to be doubtful and motivates discussion about - how to use the various tools of marketing communication? It still remains a question about the importance and scope of factors affecting customer satisfaction and loyalty, as well as the position of marketing and promotional activities.

\section{Litepature review}

The latest global crisis has seriously damaged trust among customers, their perceptions and behavior related to the banks. Competitive pricing and cutting edge technology based financial solutions are not enough to restore customers' confidence, prevent attrition and cultivate their loyalty. Human-based distribution channel remain the best manner to offer tailored banking and reward customer affinity. In order to be more efficient banks shall study the manners in which emotions influence customers' decisions and behaviors via dedicated customer relationship management electronic solutions (CRMs). Behavioral knowledge may help banks to reposition their products, features and prices in order to be more attractive and effective for the most customer, providing a competitive edge (Dedu, Nitescu, 2014).

Rebuilding of the image and creating good relationships with customers is a marketing challenge. Nowadays all firms try to in cash the corporate image to increase their revenues particularly profits depended on customer satisfaction defined "an overall evaluation based on the total purchase and consumption experience focused on the perceived product or service performance compared with pre-purchase expectations over time". So it should be clearly understood that financial services differ significantly from material goods and other service categories. Most often, when consumers buy financial services, they must give up a certain amount of money for a benefit which is to be experienced in a future time. It is therefore of paramount importance that customers perceive the services of a particular bank of high quality. Moreover, a high service quality offer on behalf of banks may lead to favorable perceptions among consumers with regard to the effort made by financial institutions with the purpose to develop their relationships with customers. This, may lead to customers' willingness to engage in the relationship, thus responding to banks' efforts by adopting a positive behavior (Radomir, Plaias, Wilson, 2015).

In most types of business, everyone is underlined by the growing importance of the internet and the media community. However in the case of financial services, this is more complicated. Nevertheless, starting with the basic mechanisms the same as to all sectors the emergence of social media in recent years has allowed marketers to reach potential customers in new, unique ways and forms. Users create profiles on a social media site or in an application designed and maintained by the social media organization. User profiles can connect with other users' profiles and create networks. Social media depend on mobile and web-based technologies to create highly interactive platforms through which individuals and communities share, co-create, discuss, and modify user-generated content. Social media might add value to consumers beyond existing e-commerce activities. Social media can complement other channels of communication with an organization and can help manage service quality for consumers enabling implementation marketing objectives, such as supporting brand awareness, decreasing marketing costs, increasing sales, and enhancing brand image by interaction with users on social media. Furthermore, companies might overview and analyze public conversations in social media to identify consumer sentiment towards their company . In addition, more over companies define rules for their employees about social media usage in cases regarding their work to avoid potential damage to the company's image (Vejačka, 2017). 
The involvement of financial institutions in social media, however, is differentiated as well as the use of the internet or mobile banking due to the strategy adopted by the bank, sometimes the possibility.

Table 1. Comparison of different levels of internet banking

\begin{tabular}{lccc}
\hline $\begin{array}{c}\text { Different levels } \\
\text { of internet banking }\end{array}$ & Basic & Intermediate & Advanced \\
\hline Informational & $\begin{array}{c}\text { Electronic manual, communication tools } \\
\text { such as emailing exchange daily report }\end{array}$ & $\begin{array}{c}\text { Search engine, downloading economic } \\
\text { reports and in format information }\end{array}$ & $\begin{array}{c}\text { Registering on the website, joining } \\
\text { discussion groups, access to other } \\
\text { websites }\end{array}$ \\
\hline Communicational & $\begin{array}{c}\text { Electronic post, suggestion and critique } \\
\text { forms, feedback forms }\end{array}$ & $\begin{array}{c}\text { Using advise tools such as calculators } \\
\text { applied in financial planning }\end{array}$ & $\begin{array}{c}\text { Video } \\
\text { conferencing, } \\
\text { service } \\
\text { development }\end{array}$ \\
\hline Transactional & $\begin{array}{c}\text { Opening bank accounts, applying for } \\
\text { cheque book, applying for bank cards }\end{array}$ & $\begin{array}{c}\text { Checking and printing account balance. } \\
\text { paying water. electricity and telephone } \\
\text { bills, transferring money }\end{array}$ & $\begin{array}{c}\text { Electronic money, electronic signature, } \\
\text { electronic cheques }\end{array}$ \\
\hline
\end{tabular}

Source: based on Sadeghi, Rasoulian, Mirzaei, Sharifipour (2017).

As described above the financial services sector is characterized by different level of using internet-based technology. Explanation may be related to the specificity of financial services or customer expectations.

Banks, whatever of their conditions, in order to improve their market position, must focus on the determinants of customer satisfaction. Engaging only into public relations activities will not deliver the expected long-term benefits.

Considering specificity of financial services, it can be shown some of the essential satisfaction factors:

1. Competitive interest rates and convenient banking - realized competitive bank charges, interest rates on loan, good value in banking products services, convenient banking hours, convenient branch location.

2. Easy access, cleanliness and responsiveness - bank provides easy-to-read understandable statement, bank employees are neat in their appearance, and employees in the bank are never too busy respond to customer request.

3. Competitive interest rates and reasonable fee - bank pays competitive interest rates on deposits, and charges reasonable service fees (Sharma, 2016).

Banks have evolved from the traditional walk-in facility towards multimedia. Being early adopters of technology, banks are continually searching for new and innovative electronic banking products and services. The recent growth in Internet and cell phone diffusion has transformed the landscape of the financial services industry, allowing for banking to be conducted with an anytime, anywhere philosophy. Banks offer many different channels to access their banking and other services. These 'channels' refer to the medium employed by the consumer to interact with the bank (Patel, Brown, 2016).

In parallel with the development of electronic banking and the web portals of financial institutions, social media extended, quickly ceased to be merely a form of private interpersonal communication. In this article we want to focus on the role of social media as the most popular and development among customers, employee and managers, but in consideration of the specific nature of the financial services segment. Social media has become a critical piece in the digital ecosystem and is measured via key metrics focusing on brand awareness, customer engagement and customer service excellence. Banks also leverages social listening and high-level platform data (such as Facebook likes and Twitter followers) to inform dashboards for executives. Bank's social media strategy 
is focused on executing their brand campaign, as well as philanthropic and sponsorship-based programs, focusing on key areas: customer service, contextual product information, always-on 'consideration' content, and community and promotional offers (Marshall, 2016).

Social media is used as a news vehicle, a political sounding board, a consumer forum and a communication tool for businesses. Bankers clearly see the value of social media; in a survey published recently by $A B A$ on the state of social media in banking, $76 \%$ said social media was important to their institution. Despite that, many banks are still only in the early stages of their social media journeys: only $24 \%$ of bankers have been using social media for more than five years. The rest are either just starting out (63\%), planning to do so in the next 1 to 2 years (5\%), or have no plans to use social media at all (9\%) (Meinert, 2017).

Also United Bankers' Bank recently reviewed the social media presence of 250 customer banks. The study found no direct correlation between the asset size and the number of "likes" a particular bank received on their Facebook page. About $80 \%$ of banks studied by UBB hadn't created a social media presence. UBB found they still had a social media presence even though they didn't create social media pages. It is best to be prepared for control the conversation by creating own social media presence and monitor social media to be aware of what's being said about bank (Holt, 2015). So it can be argued that the activity in social media is not only desirable but also forced.

\section{Method}

Theoretical part of the article is based on a review of the literature and refers to the issue of financial institutions image, factors which generate satisfaction, and the relations between these factors and the messages that are generated in social media by banks. The empirical part was an attempt to confirm the thesis and to identify the reasons for the limited position of social media in decisions regarding financial services. The empirical part is based on own research, conducted in 2017, on a sample of 304 respondents living in the Podkarpackie voivodship. The structure of the research sample reflects the structure of the population (quota sampling). The research was conducted through face-to-face interviews using an interview questionnaire includes 83 questions with different measuring scales. Presented research results include studies carried out in the department of marketing and entrepreneurship of the University of Rzeszów in the area of the marketing activities and development of the enterprises.

\section{Resullts}

It should be noticed that the sample size and geographical location of respondents probably cause limitations of the studies and influence the results of the survey. Other researchers may get different results, but the ones presented in this article may be a voice in discussion and an indication of new directions or research topics. Purchase decisions are taken by the customer based on various factors. It depends on the customer's characteristics and type of products or services. The research concerned on the determinants of service purchasing. According to the purpose of the article, attention has been focused primarily on the importance of social media in different types of services (Figure 1). 


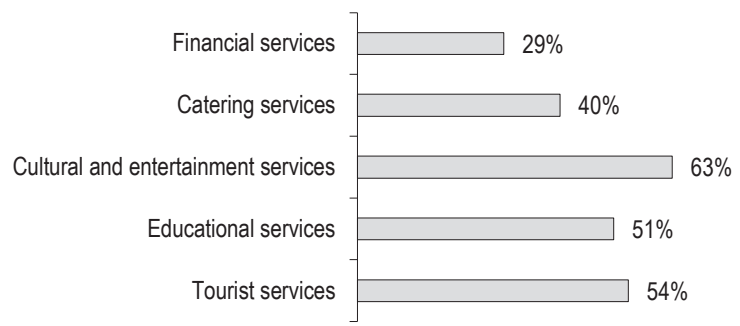

Figure 1. Opinions concerning selected services expressed in social media as the most important factor influencing purchase decisions

Source: own calculations.

The research proves that information publish in the social media are important in purchasing decisions. The impact of this information on consumers' decisions varies, however, depending on the type of service. Mostly, the information published in social media determines the decision to purchase cultural and entertainment services, followed by tourism and educational services. For each of these groups, more than $50 \%$ of the respondents declare that these media are the most influencing data source. On the other hand, social media makes decisions about the choice of financial services to the smallest extent (important for $30 \%$ of the respondents). Looking for an attempt to explain the described phenomena, it is necessary to refer to the specific nature of the services, especially financial services may be described as sensitive, because not everyone wants to disclose information about their financial situation, including borrowed or invested funds. Meanwhile, participation in cultural and entertainment discussions using social media is a good opportunity to look for attractive events or contacts.

The varied importance of information published in social media influences the frequency of searching the informations about particular services (Figure 2).

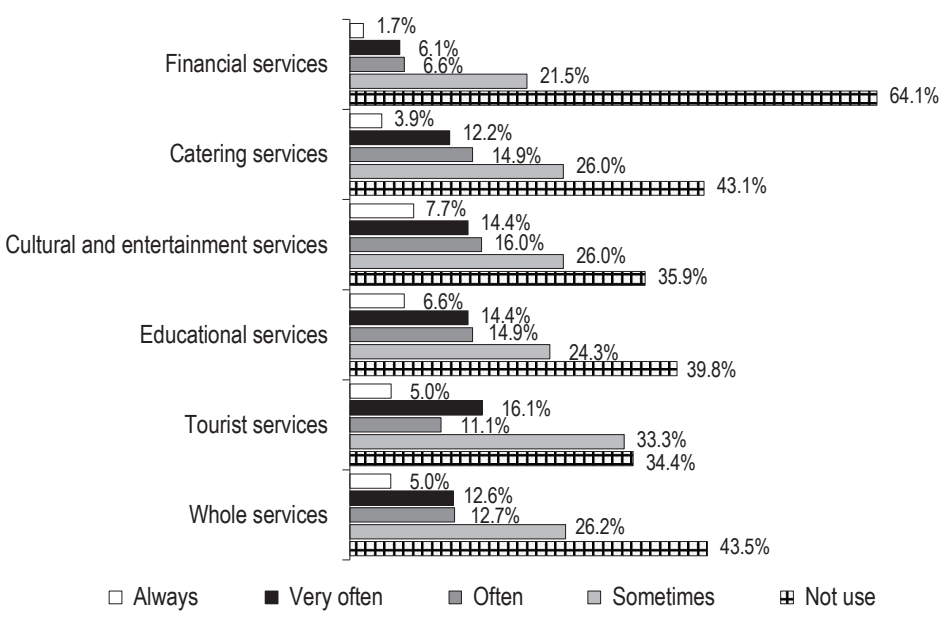

Figure 2. Frequency of using information in social media before purchasing selected services Source: own calculations. 
According to the research more than $50 \%$ of requested customers search information about services using social media. However, the frequency of searching for this information is different for each type of service. In the group of services for which respondents declare that they are always looking information about them on social media, may be listed (in order) cultural, entertainment, educational and tourist services. Before buying of these services more than $60 \%$ of the respondents declare using discussed media for information. The smallest importance of social media may be observed in financial services, where nearly $65 \%$ of respondents declare that they never use information contained in social media before purchasing. Less than $2 \%$ of respondents admit that these source of information about the offer of services is always used before buying. The observed differences in the importance of using social media before undertaking decisions of buying services, including financial services, inspirate to recognize the conditions of this importance. Therefore, during research of the importance of social media for respondents' preferences, their age, sex and education were analyzed (Figure 3).

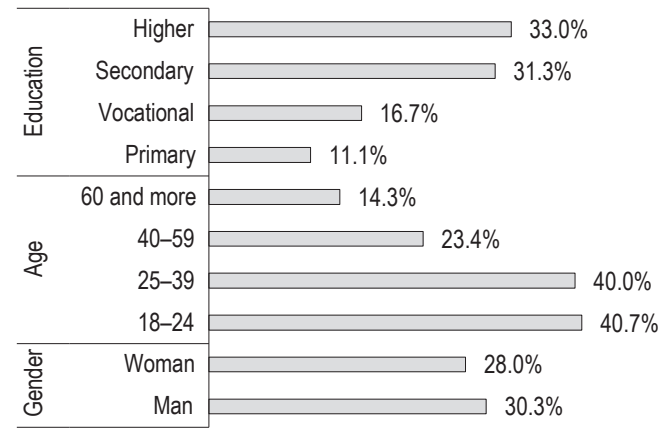

Figure 3. The structure of respondents considering information published on social media networks in their purchase decisions of financial services

Source: own calculations.

Collected data proves a large difference in the inclusion of information from social media in purchase decisions. While in the case of gender, the impact of social media is quite similar, with a slight advantage for men, in the other criteria that characterize respondents, the divergence is larger. The level of education of the respondents was more related to the diversification of the impact of social media. People with higher education more often admit that information from social media creates their market choices. In the case of people with higher education, almost one third of the respondents consider social media in their decisions, whereas in the group of people with basic education, $1 / 10$ respondents report similar influences. Social media has the greatest impact on young people, about $40 \%$ of them declare it. Older respondents were not interested in social media because of their habits and troubles with using information and communication technologies (ICT). The explanation of the described rules is different media preferences by different customer groups, where young, learning or higher educated are more active users of social media networks.

The analysis indicates also that information published by the social media community is only one of several factors that the clients takes into consideration (Figure 4). 


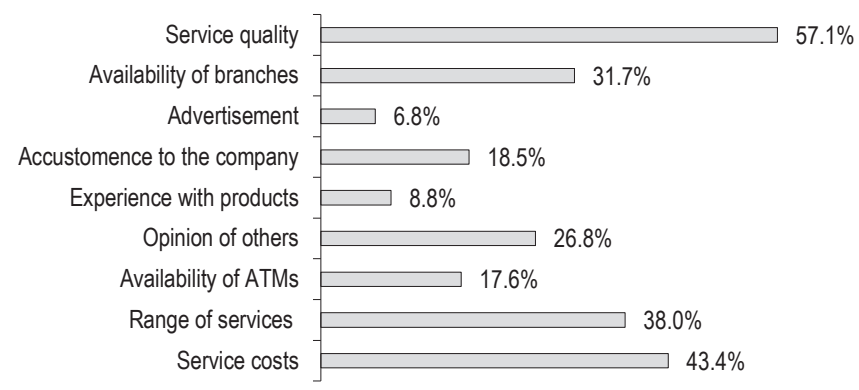

Figure 4. Determinants of choosing a financial services provider

Source: own calculations.

The decision of purchasing the financial services depends of many factors. However their importance are different. The most important factor in this process is the quality of customer service, including personalized and non-anonymous contact with the customer, method of the offer presentation, time spent on the service, the simplicity of the presented offer. Another important factor is the costs of services, including fees and commissions which are equivalent of the price for the service. Slightly less importance was observed in the extent of the offer, which fulfilled the diverse needs of customers. Physical accessibility of the facilities, the number of service branches, accessibility and parking, or the availability of ATMs are also important for customers. On the fifth position in the rank, respondents indicated opinions of others customers, as a factor influencing their preferences. These opinions may relate to personal contacts as well as expressed by social media. The smallest importance was observed in the case of advertising and experience with the offered products. Referring to the basic thesis of the article, it was confirmed that the position of social media in the decision of purchasing financial services against other factors is generally meager.

\section{Limitations}

The research results included in this article are only part of the study on the importance of social media. Considering that the overall objective of the study was very wide and the article used only a small piece of the collected data, there are some limitations of the conducted research thesis. The first limitation is the consequence of extended interview questionnaire caused the respondent's fatigue, and could have resulted in hasty answers. The second limitation - research was conducted in only one province, (Podkarpackie voivodship), which is only a small part of society, so the results can not be generalized for the entire population. Another limitation is the number of respondents. Although the sample of 304 respondents may be sufficient for regional studies, transferring of research results to a larger population will decrease the reliability of the study.

\section{Conclusions}

Social media may be an important source of data for some customers, preceding and facilitating the selection and purchase of products or services. The informations provided on social media are more important in the case of services, whose intangibility makes it impossible to verify the quality before purchase. Therefore, the opinions of other people who got the experience and knowledge about the availability of services and their quality may be the 
way to verify the market offer of companies. In the result of specificity and complexity of the financial services the information published on social media may not be comprehensive enough to cease promoting services outside the social networks. Development trend of social media suggests an increasing importance of published information for consumer preferences and purchasing decisions, including in the financial services sector. However, nowadays financial services communications should not be concentrate only through social media, as a large group of users outside of this community would not be able to be acquainted with the market offer.

\section{References}

Dedu, V., Nitescu, D. (2014). Banking relationship management - a new paradigm? Theoretical and Applied Economics, 21, 4 (593), $7-22$.

Holt, K. (2015). Take a look into your bank's social media presence. North Western Financial Review, August, 27.

Marshall, J. (2016). Customers' changing expectations. Global Finance, September, 20.

Meinert, M. (2017). What's your social status? Aba Banking Journal, May/June, 48-49.

Patel, K., Brown, I. (2016). Towards a theory of multi-channel banking adoption amongst consumers. Electronic Journal Information Systems Evaluation, 3 (19), 137-157.

Radomir, L., Plaias, I., Wilson, A. (2015). Bank service and relationship quality as drivers of consumers' attitudinal loyalty. Romanian Journal of Marketing, 2, 62-74.

Sadeghi Rad, H., Sharifipour, A., Rasoulian, A., Mirzaei, M. (2017). New strategy to create customers' loyalty to investment and its impact on economic initiatives. International Journal of Management, Accounting and Economics, 4 (4), 431-442.

Sharma, K., Mehra, A. (2016). Services quality and customer satisfaction as antecedents of corporate image: a study of banking sector. The Journal of Management Awareness, 2 (19), 1-16.

Vejačka, M. (2017). Social media marketing in comparison with other forms of marketing in the slovak banking sector. Market-Tržište, 1 (29), 23-38.

Cite this article as: Cyran, K., Dybka, S. (2018). The importance of social media in financial services' selling. European Journal of Service Management, 1 (25), 41-48. DOI: 10.18276/ejsm.2018.25-05. 